\title{
ANALYTICAL STUDIES OF STRAIN-STRESS DISTRIBUTION OF ROCK MASSIF AT RECOVERY ROOM T-JUNCTIONS
}

\author{
Grigoryi Nikolaevich Karpov \\ Ph.D., associate professor, Department of Mining Engineering \\ Saint-Petersburg Mining University, Russian Federation, 199106, Saint-Petersburg, \\ Vasilievski ostrov, 21 linia, 2, Russia \\ Evgeni Rostislavovich Kovalski \\ Ph.D., associate professor, Department of Mining Engineering \\ Saint-Petersburg Mining University, Russian Federation, 199106, Saint-Petersburg, \\ Vasilievski ostrov, 21 linia, 2, Russia \\ Artem Valerievich Leisle \\ $\mathrm{Ph} . \mathrm{D}$., associate professor, Industrial Safety Department \\ Saint-Petersburg Mining University, Russian Federation, 199106, Saint-Petersburg, \\ Vasilievski ostrov, 21 linia, 2, Russia
}

\begin{abstract}
Russia's coal industry has a clear trend towards increasing load on mining faces equipped by coal-face systems. With increase of coal-face equipment output, financial losses from the equipment downtime also increase. Downtime of fully-mechanized faces can have different causes, but downtime in disassembly is inevitable, and for this reason, minimizing downtime duration is paramount for improving mines operations efficiency. The main causes of repositioning duration increase are roofing rocks collapses into the work area, the most intensive collapse of roofing rocks occurs at the end sections of a recovery room. One of effective modes of enhancing the stability of roofing rocks is rocks destressing. The study objective is determining the parameters of destressing recovery room immediate roofing rocks in developing a gently-sloping thick coal seam on the base of the finite element mining and geomechanical model. The paper describes the methodology of developing a model and design models for assessing the components of the stress-strain state of the coal-bearing massif in the area adjacent to the recovery room. Assessment was conducted of the parameters of limit state zones in a coal seam and in the roofing rocks of the recovery room. Justification was provided for the parameters of the mode of immediate roofing destressing from the stresses at the end sections of the recovery room via drilling relief boreholes. The determined parameters of the technology include: the width of the
\end{abstract}


destressing zone, the depth of the relief boreholes, their diameter, the boreholes' spacing interval and the period of time until the passage of the longwall, for which they must be drilled.

Keywords: gently-sloping coal mines, underground mining of coal, longwall face move, recovery room, destressing of massif, stability of immediate roof, stressstrain state, relief boreholes.

Cite this Article: Grigoryi Nikolaevich Karpov, Evgeni Rostislavovich Kovalski and Artem Valerievich Leisle, Analytical Studies of Strain-Stress Distribution of Rock Massif at Recovery Room T-Junctions. International Journal of Advanced Research in Engineering and Technology, 10(2), 2019, pp. 596-607.

http://iaeme.com/Home/issue/IJARET?Volume=10\&Issue $=2$

\section{INTRODUCTION}

Implementation of reliable highly productive longwall sets of equipment at today's mines in mining gently-sloping coal seam enables to achieve loads on the mining face at the level of 50 thousand tons per 24 hours and more. Under such conditions, maintenance of reserve line of the working face front is not required, and it also can cause increase of mining cost price because of reducing the spatial concentration of mining works.

"Longwall mines" are enterprises having a maximal spatial concentration of works, are the most competitive. However, enterprises of this type are characterized by a high cost of the downtime of a longwall set of equipment. Out of the overall list of downtime of a longwall set of equipment, the period of installation and disassembly works in repositioning the longwall to a new site [2,22] deserve special attention. This period is characterized by not only a relatively long duration, but it is also inevitable in the application of longwall systems. From the viewpoint of safety, labor intensity and organization of works, the most complex stage of repositioning is disassembly of a longwall set of equipment. In the vast majority of cases, increase of downtime duration is caused by collapse of the rocks of immediate roofing into the working space of the recovery room.

Thus, increasing the stability of the rocks of recovery room immediate roofing is one of important problems for enhancing the efficiency and safety of coal-face works depending on the great number of factors $[3,5,7,9,16,20]$. In turn, studying the processes of the massif loss of stability, caused by mining, is a complex mining and geomechanical problem $[1,8,14,18,21]$, which can be effectively solved via application of numerical modeling methods.

The conducted studies $[4,6,23]$ demonstrate that the highest intensity of collapses of rocks of immediate roofing is typical for the end sections of the recovery room, adjacent to the interfaces with the local mine workings. As a method of enhancing the stability of the rocks of immediate roofing in the longwall face space, drilling relief boreholes is recommended $[10,17]$. The article describes the studies performed via numerical models and aimed at evaluating the feasibility of application of this technology in disassembly and at determining the technology parameters: the width of destressing zone, the depth of relief boreholes, their diameter, the boreholes' spacing interval and the duration of the period until the passage of the longwall (they should be drilled within this period).

\section{RESEARCH METHOD}

Modeling the parameters of the stress and strain state of the rock massif adjacent to the recovery room, was conducted via the finite elements method in plane deformation setting, which significantly reduces the labor intensity of creating finite elements' models, simplifies breaking 
down the models into elements and lowers the requirements to the required computational capabilities for calculating the models. Application of plane deformation setting in this case is justified, as all the simulated mine workings are extended in length compared to their transversal dimensions and, in addition, such a target setting provides a solution "with a margin" compared to a solution in a volumetric setting [13].

Development of the computer model and schemes required for carrying out the designated tasks, was conducted in accordance with the technological sequence of coal face operations advancing:

Stage 1. Modeling the virgin ground massif and formation of the initial stress field.

Stage 2. Formation of the cavity of the mined-out area of the adjacent extraction pillar and the preparatory workings of the studied area (here, an assumption is made about "conditionally instantaneous" formation of cavities, and the preparatory workings are assumed as having no support, to simplify the calculations).

Stage 3. Formation of the cavities of relief boreholes in the zone of the future disassembly working ahead of the longwall coal face.

Stage 4. Longwall approaching the destressed zone and redistribution of the bearing pressure in the roofing via artificially created seam mechanical compliance (because of the deformation and gradual destruction of borehole-to-borehole pillars).

For achieving the set objectives, two mining and geomechanical models (design schemes) were developed:

1. Cross-section of the extraction pillar mined with the longwall mining system along the stretch in ascending mining of mine field (Figure 1). Preparation of the extraction area is performed via two-heading entries. The depth of the mining is $182-200 \mathrm{~m}$. The longwall length is $200 \mathrm{~m}$. The width of pillars designated for protection of entries $-40 \mathrm{~m}$. The thickness of the seam is $5 \mathrm{~m}$. The dip angle is $5^{\circ}$. The other parameters of the model are presented in table 1 . This scheme is designated for determining the required drilling depth of relief boreholes at the end sections of the recovery room.

2. The longitudinal section of the extraction pillar along the mining panel entry in the geological and mining conditions described above (figure 2). In the zone of the scheduled location of the recovery room, the coal seam is attenuated with the boreholes drilled from the panel entry parallel to the coal face. This scheme is designed for determining the relief boreholes' spacing interval, boreholes' diameter and the width of the destressing zone.

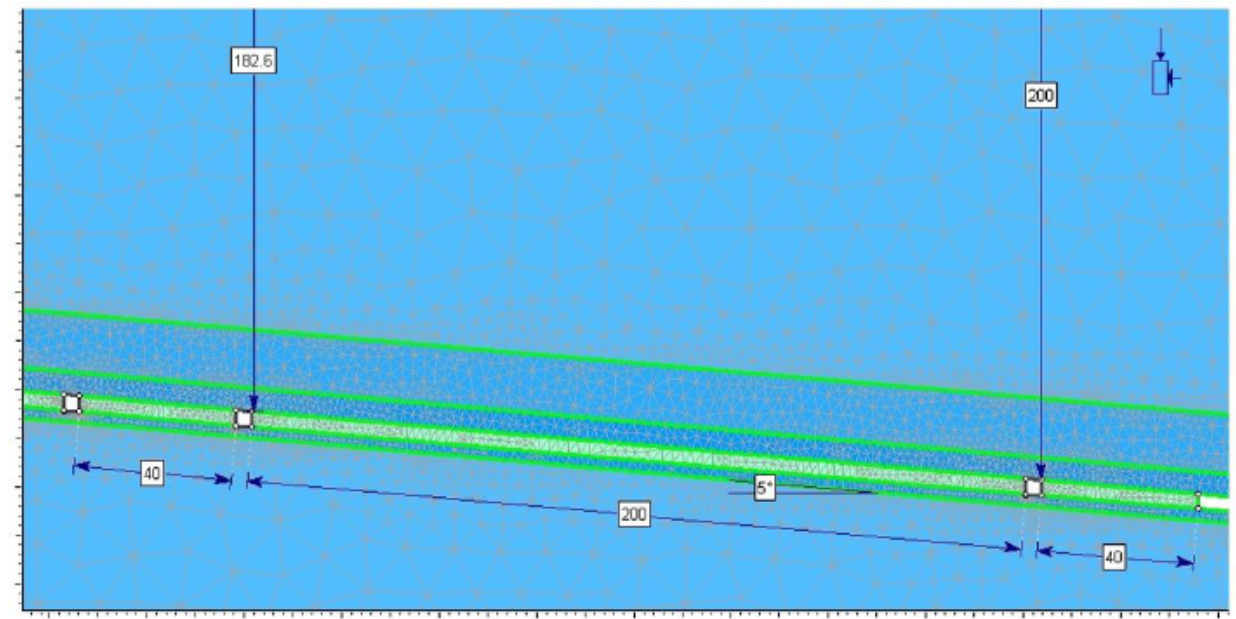

Figure 1 - Fragments of design scheme for determining the depth of destressing 


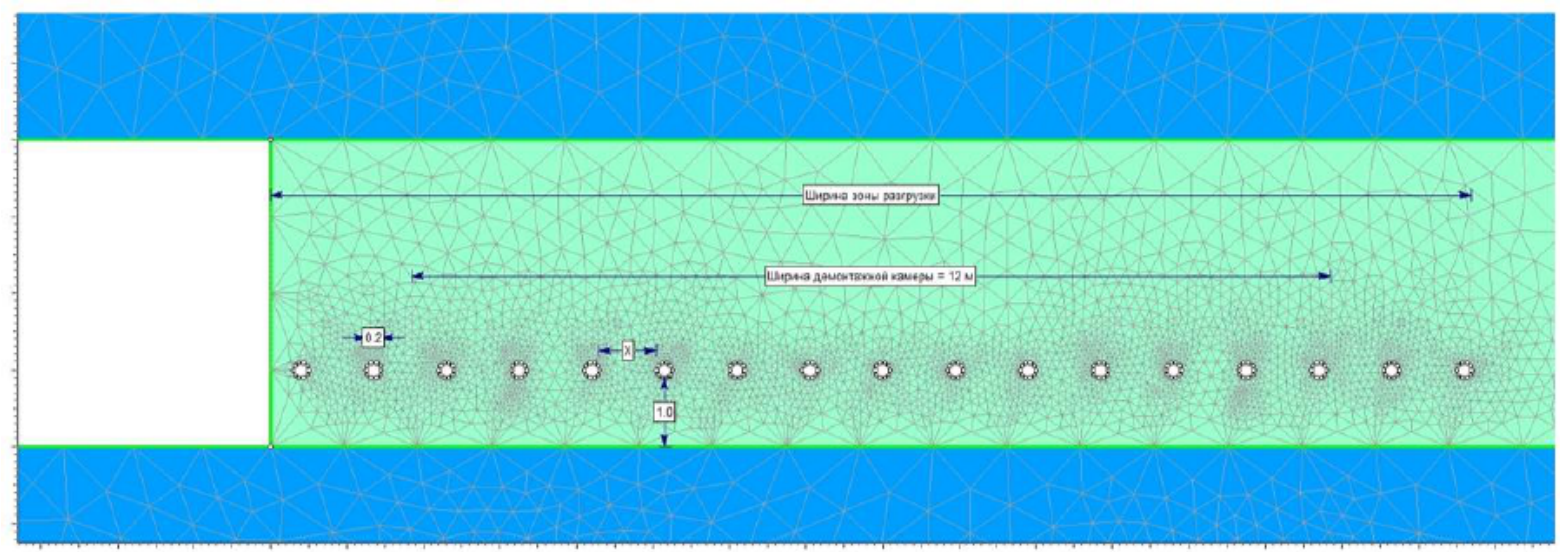

Figure 2 - Design scheme for determining the distance between relief boreholes

Table 1 - Source physical and mechanical properties of rocks, used in constructing the mining and geomechanical model.

\begin{tabular}{|c|c|c|c|c|c|}
\hline Seam name & $\begin{array}{l}\stackrel{\infty}{\leftrightarrows} \\
\stackrel{0}{0} \\
\stackrel{0}{0} \\
\stackrel{\Xi}{\Xi} \\
\sum\end{array}$ & 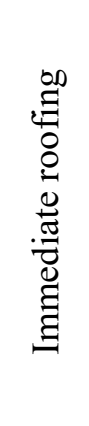 & 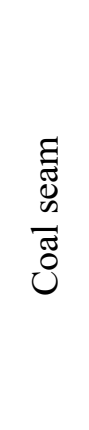 & 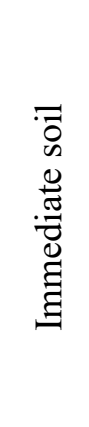 & 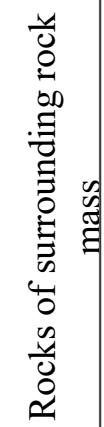 \\
\hline Seam thickness, $\mathrm{m}$. & 14,8 & 5,7 & 4,2 & 2,8 & - \\
\hline Volumetric weight, $\mathrm{t} / \mathrm{m}^{3}$ & 2,42 & 2,33 & 1,36 & 2,3 & 2,38 \\
\hline $\begin{array}{l}\text { Unixial compression strength } \sigma_{\text {Сж}}, \\
\mathrm{kgf} / \mathrm{cm}^{2}\end{array}$ & 570 & 210 & 135 & 220 & 450 \\
\hline Tensile strength $\sigma_{\mathrm{p}}, \mathrm{kgf} / \mathrm{cm}^{2}$ & 15 & 10 & 5 & 10 & 13 \\
\hline $\begin{array}{l}\text { Young's modulus } \\
\mathrm{E} \cdot 10^{-5}, \mathrm{kgf} / \mathrm{cm}^{2}\end{array}$ & 2,16 & 1,77 & 0,25 & 1,72 & 1,99 \\
\hline Poisson's ratio, $\mu$ & 0,34 & 0,28 & 0,26 & 0,26 & 0,31 \\
\hline Adhesion, $\mathrm{kgf} / \mathrm{cm}^{2}$ & 172 & 82 & 35 & 76 & 143 \\
\hline Angle of internal friction, degrees & 42 & 37 & 36 & 39 & 40 \\
\hline
\end{tabular}

As the criterion for the stability of the rock massif, in selection of the relief boreholes' spacing interval, the condition is adopted of the loss of the bearing capacity by the massif, the condition is assessed along the zones of non-linear deformations' development (by MohrCoulomb theory) [15].

\section{RESULTS AND DISCUSSION}

Figure 3 presents the pattern of the distribution of the maximal stresses in the vicinity of the future recovery room, with consideration of the longwall bearing pressure action. 


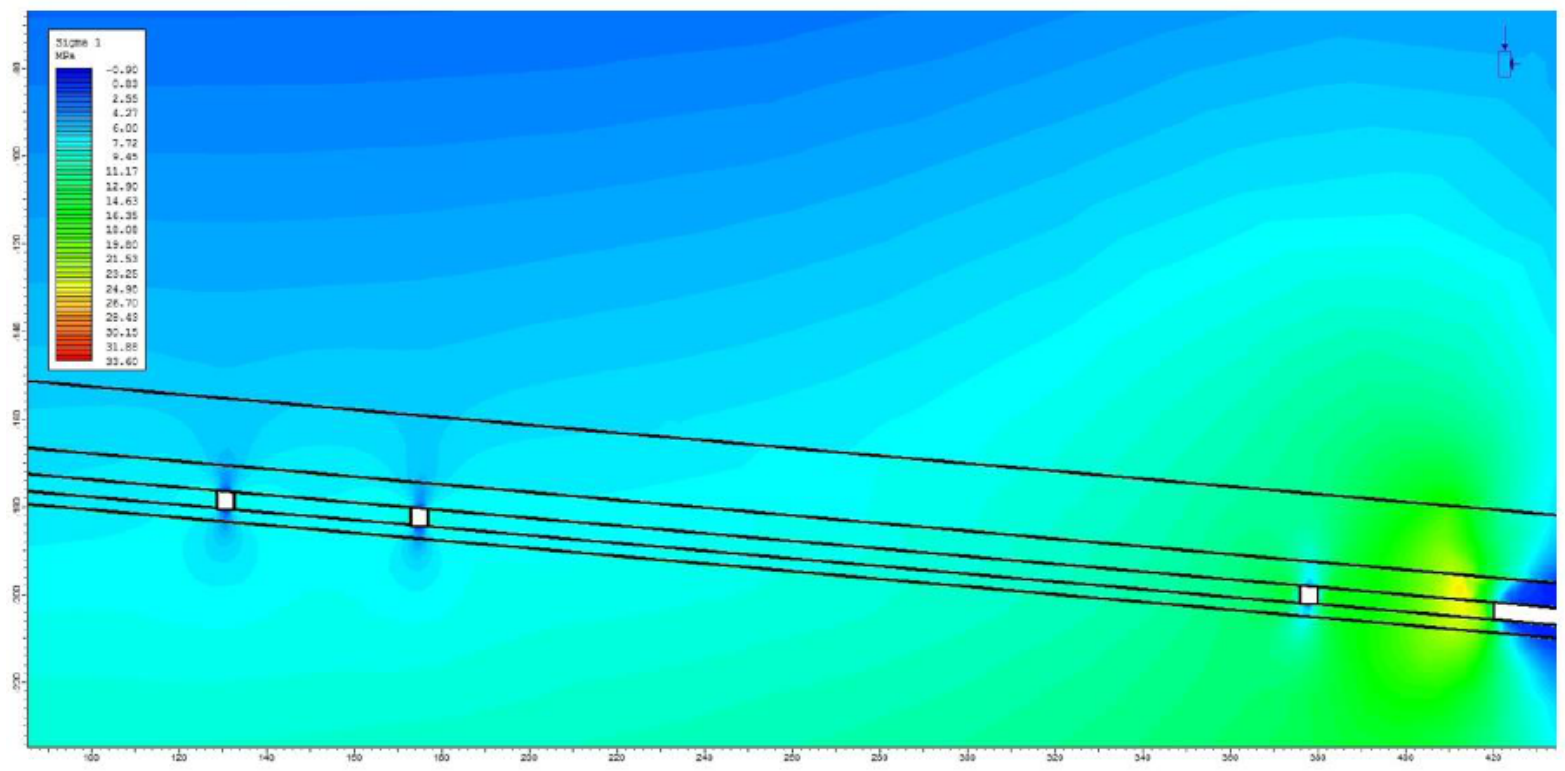

Figure 3 - Distribution of vertical stresses in rocks of recovery room roof

The presented pattern shows that the highest stress concentration occurs in the area of the interface of the recovery room with the head entry separated from the mined-out area of the adjacent previously mined-out extraction coal pillar of $40 \mathrm{~m}$. in width. The maximal values of the stresses formed at the seam end sections, are displaced down the massif which is caused by plastic, and not elastic drive of seam deformation.

Figure 4 demonstrates the graph reflecting the value of the stresses occurring in the rocks of immediate roofing at the end section of the recovery room adjacent to the head entry.

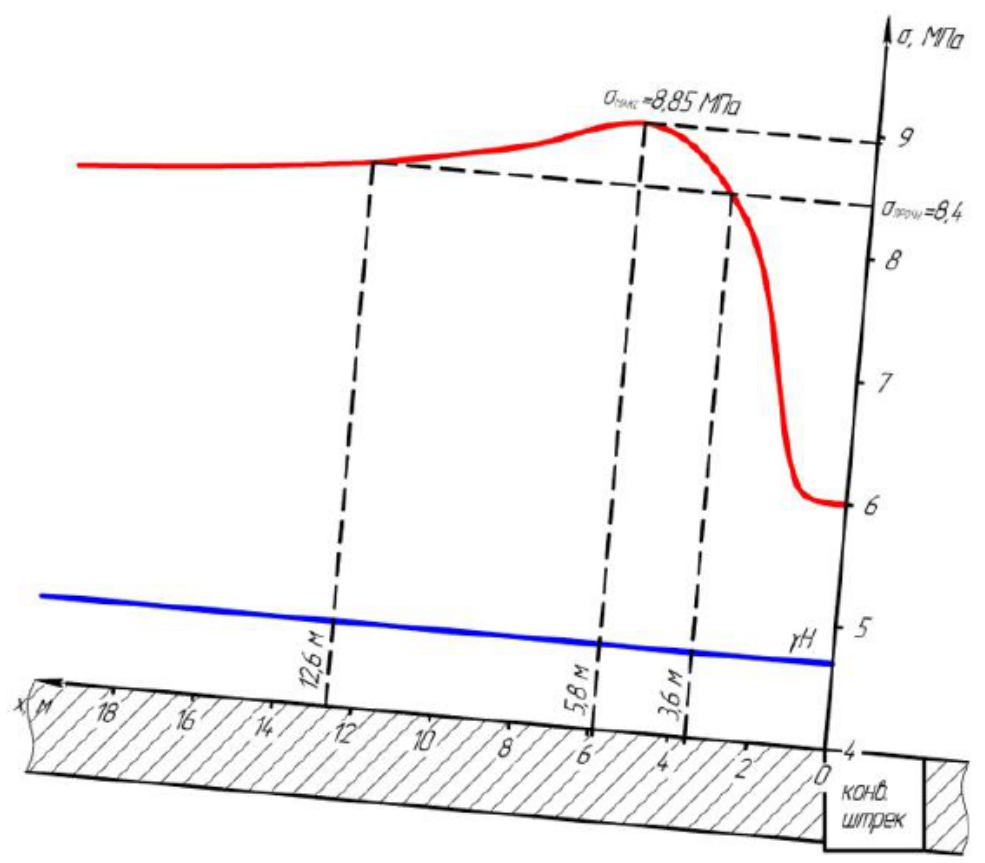

Figure 4 - Distribution of stresses in the rocks of the immediate roofing of recovery room along the length 
Because the selvedge parts of the massif have freedom of movement, this study assumes that the selvedge part is in the stressed state close to uniaxial compression. Such an assumption enables to use simple physical quantities for analyzing the roofing stability - compressive stresses in the selvedge part of the massif and the uniaxial compression strength limit of the immediate roofing rocks.

The graph in figure 4 demonstrates that in the roofing area of $12.6 \mathrm{~m}$. in width, located at some distance from the head entry $(3.6 \mathrm{~m}$.), the value of the vertical stresses exceeds their compression strength limit of $8.4 \mathrm{MPa}$ adopted with consideration of the structural attenuation factor for highly fractured rocks $K_{\mathrm{c}}=0.4$. The maximal value of the stresses is $8.85 \mathrm{MPa}$, and it is located at the distance of $5.8 \mathrm{~m}$. away from the coal seam selvedge part.

A similar graph of the distribution of vertical stresses in the immediate roofing of the recovery room in the area adjacent to the tail entry, is presented in figure 5.

The obtained values of the depth of proliferation of the zones of increased stresses are confirmed by the results of underground investigations, which indicate the reliability of the applied method of numerical modeling and the elaborated mining and geomechanical model $[6]$.

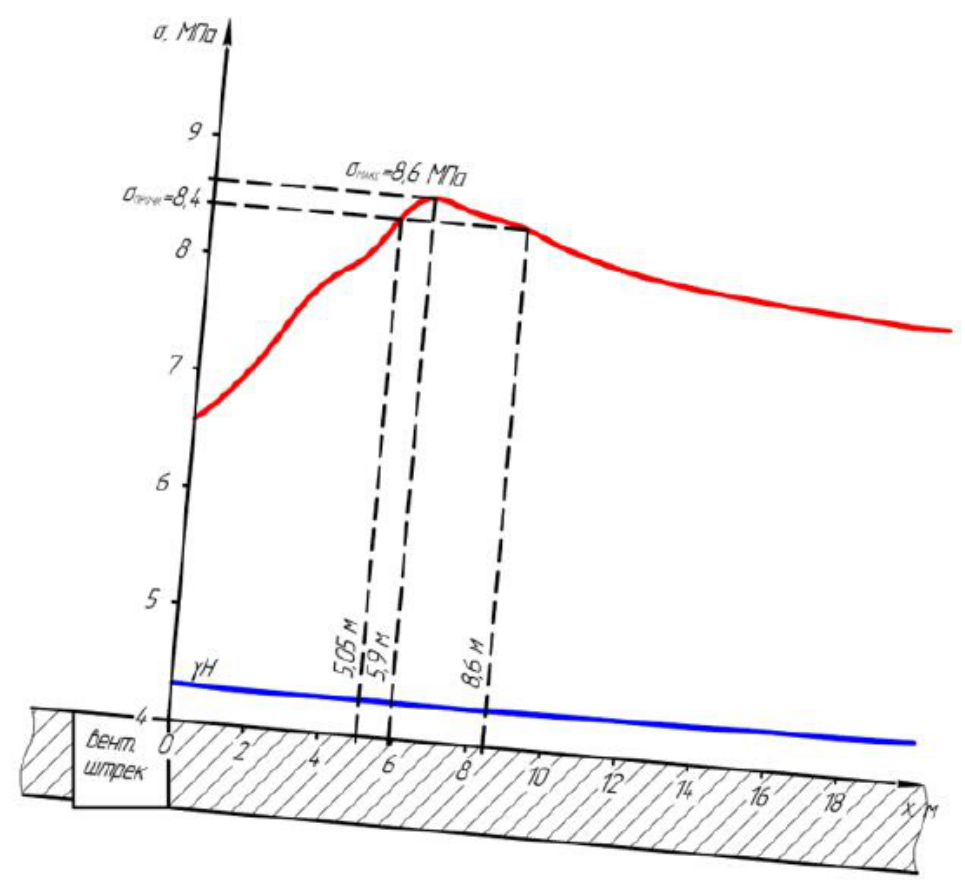

Figure 5 - Distribution of stresses in the rocks of the immediate roofing of recovery room along the length from the tail gate.

X-axis: tail entry

Satisfactory convergence of the obtained values with the observed values in practice enables to make such a calculation of the width of the zones of increased stresses for different depths of mining. The graph shown in figure 6, was constructed based on the results of the calculation, the graph enables to determine the width of the zones of increased stresses proliferation for different mining depths. The obtained graph conforms to the well-known concepts of the linear nature of the stress values increase with depth. 


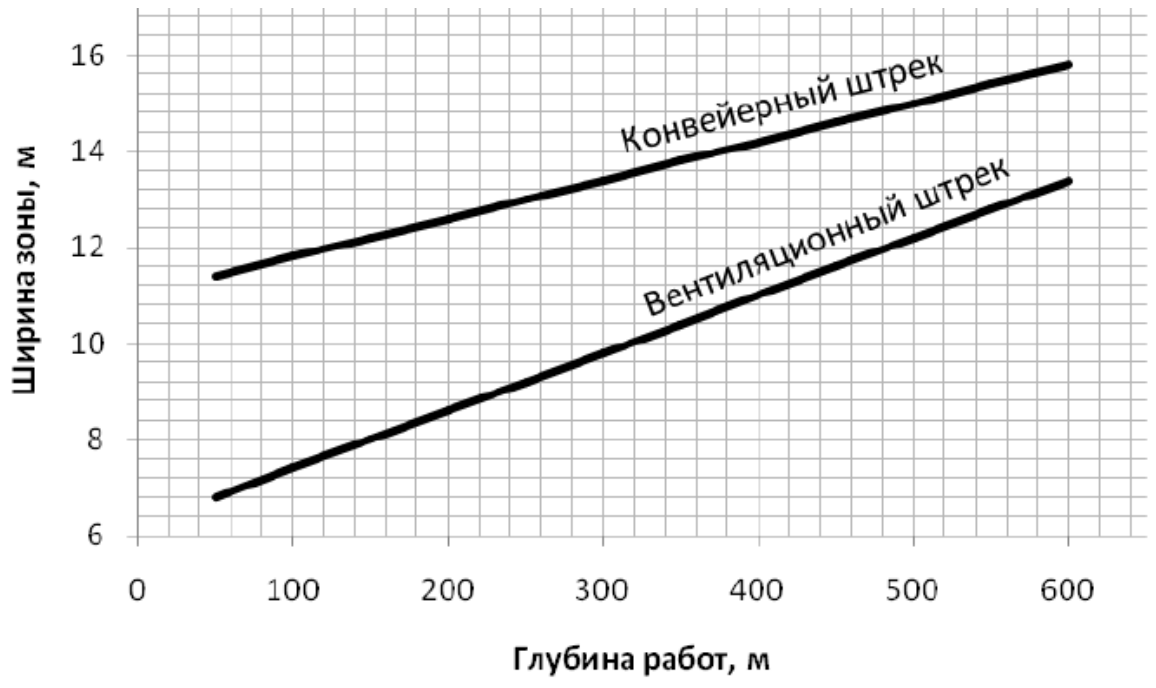

Figure 6 - Graph for determining the width of the zones of stress concentration at end sections of recovery room

Y-axis: Width of zone, $\mathrm{m}$.

Graphs:

(Above) head entry

(Down) tail entry

The parameter of the depth of coal seam relief should be adopted of no less than the proliferation depth of increased stress zones. For example, for the selvedge part of the recovery room, from the head entry side, at the depth of $200 \mathrm{~m}$., this parameter will be not less than 12.6 m. (see figure 4).

Technologically, the destressing depth can be ensured via drilling boreholes being parallel to the coal face. From the viewpoint of cost-effectiveness and workability of the application of the recommended mode, it is reasonable to create relief boreholes at the stage of drilling degassing boreholes $[11,19]$. This will enable to introduce the proposed activity into the flow chart of mining the panel with minimal organizational changes. In the considered example, the relief boreholes diameter is assumed as being equal to $0.2 \mathrm{~m}$.

For determining the distance between borehole walls, in which, the mechanical compliance of the seam selvedge part is ensured, several patterns were constructed of distribution of plastic ranges in stress along the design scheme 2 (figure 7). The dimensions and distribution pattern of the zones were studied at various width of inter-borehole pillars (that is, with different values of the distance between borehole walls). The analysis demonstrated that the biggest distance, in which the coal pillar between the boreholes in bearing pressure zone transforms into plastic state and ensures the stable roofing condition (under the studied conditions), was $75 \mathrm{~cm}$. (figure 7.). With a smaller distance $(0.5 \mathrm{~m}$.), destruction of inter-borehole pillars occurs before approaching a bearing pressure wave, and with a bigger distance $(1.0 \mathrm{~m}$.), no destruction occurs even in the bearing pressure zone. 


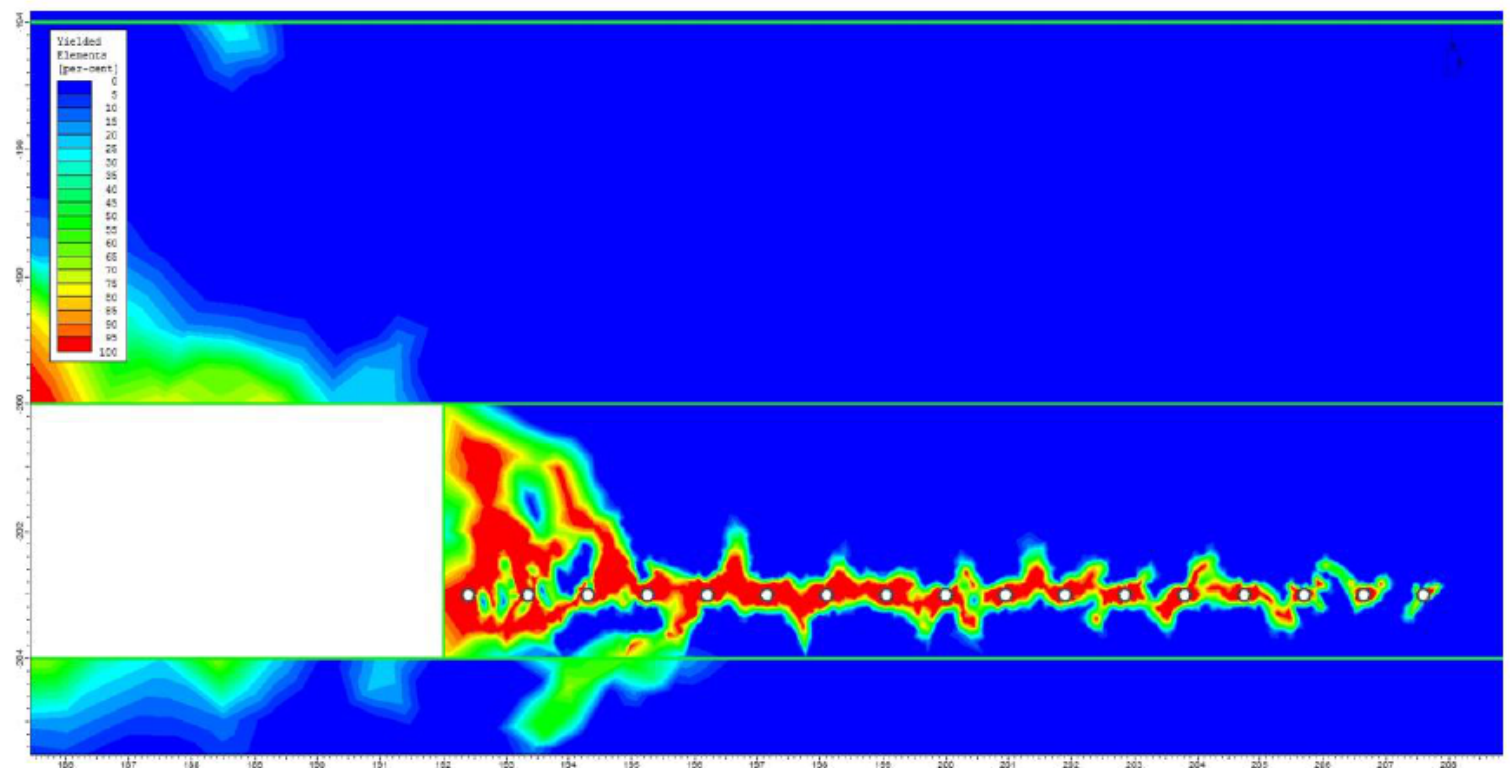

Figure 7 - Distributions of plastic ranges in stress in drilling relief boreholes with spacing interval of $0.75 \mathrm{~m}$.

The figure shows that inelastic deformations develop in all inter-borehole pillars. Also, the selvedge part of the seam gets destroyed at the depth of about 1-1.5 m, which is the outcome of the aggregate action of the longwall bearing pressure and the attenuation effect of boreholes. At the same time, the condition of the rocks of the immediate roofing above the destressing zone is stable.

The pattern of the distribution of rocks displacement in the massif is presented in figure 8 . The maximal value of the roofing lowering above the bottomhole region was $0.13 \mathrm{~m}$, which corresponds to its stable state by the data of the observations at coal mines, and also confirms the conclusion about the stable condition of the roofing, stated on the base of the analysis of plastic deformations (figure 7).

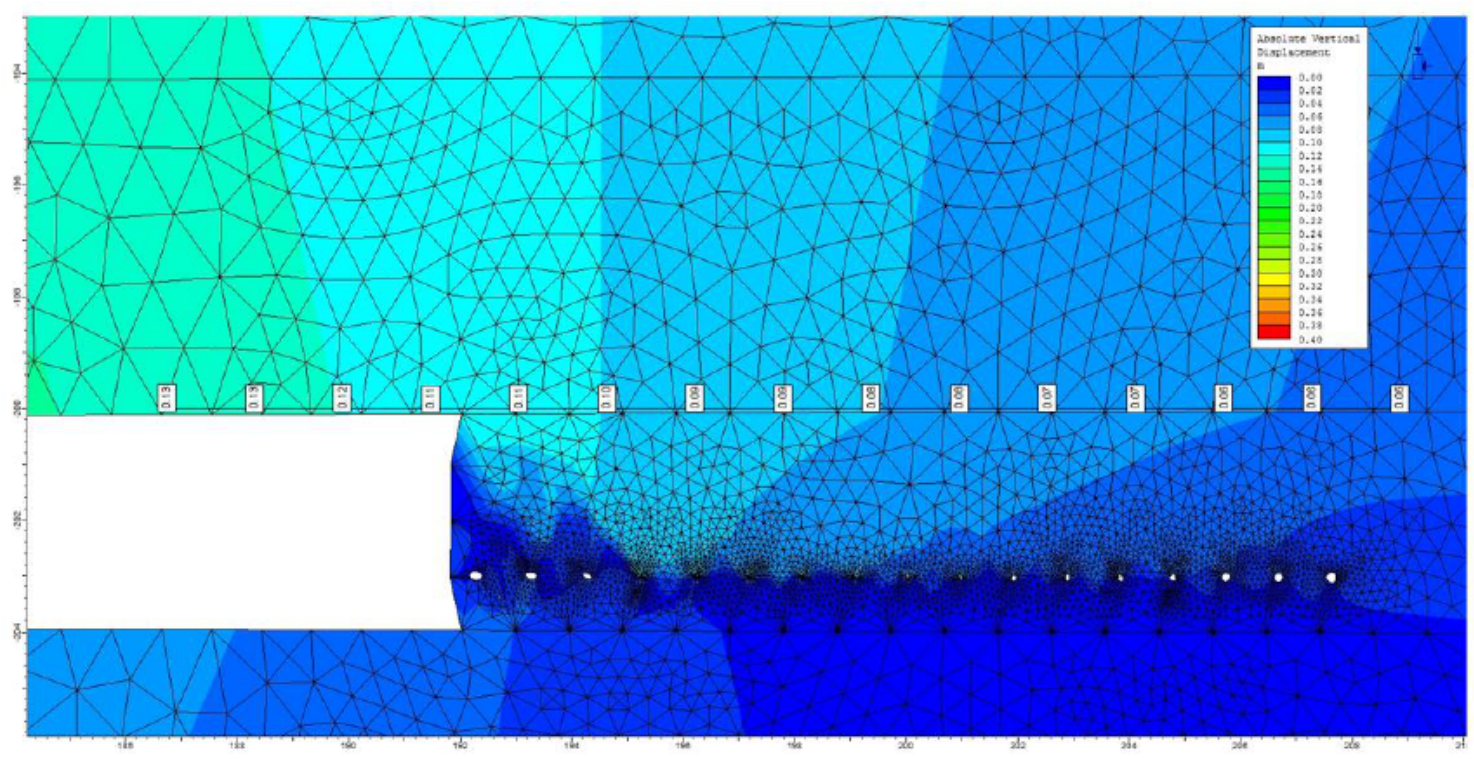

Figure 8 - Distribution of displacements of rocks in the massif when drilling relief boreholes with $0.75 \mathrm{~m}$. spacing interval 
Increasing the relief boreholes' spacing interval up to $1.0 \mathrm{~m}$, as figure 9 demonstrates, drastically decreases the destressing efficiency. In so doing, pillars operate in the regime of "rigid", not "mechanically compliant", and, as a result, the roofing ends up being "crushed" by the action of the longwall bearing pressure and transforms into a sub-marginal state. Subsequently, in coal face advancing in the process of recovery room formation, rocks occurring above the bottomhole space, will have reduced bearing capacity, such rocks are prone to spontaneous collapses.

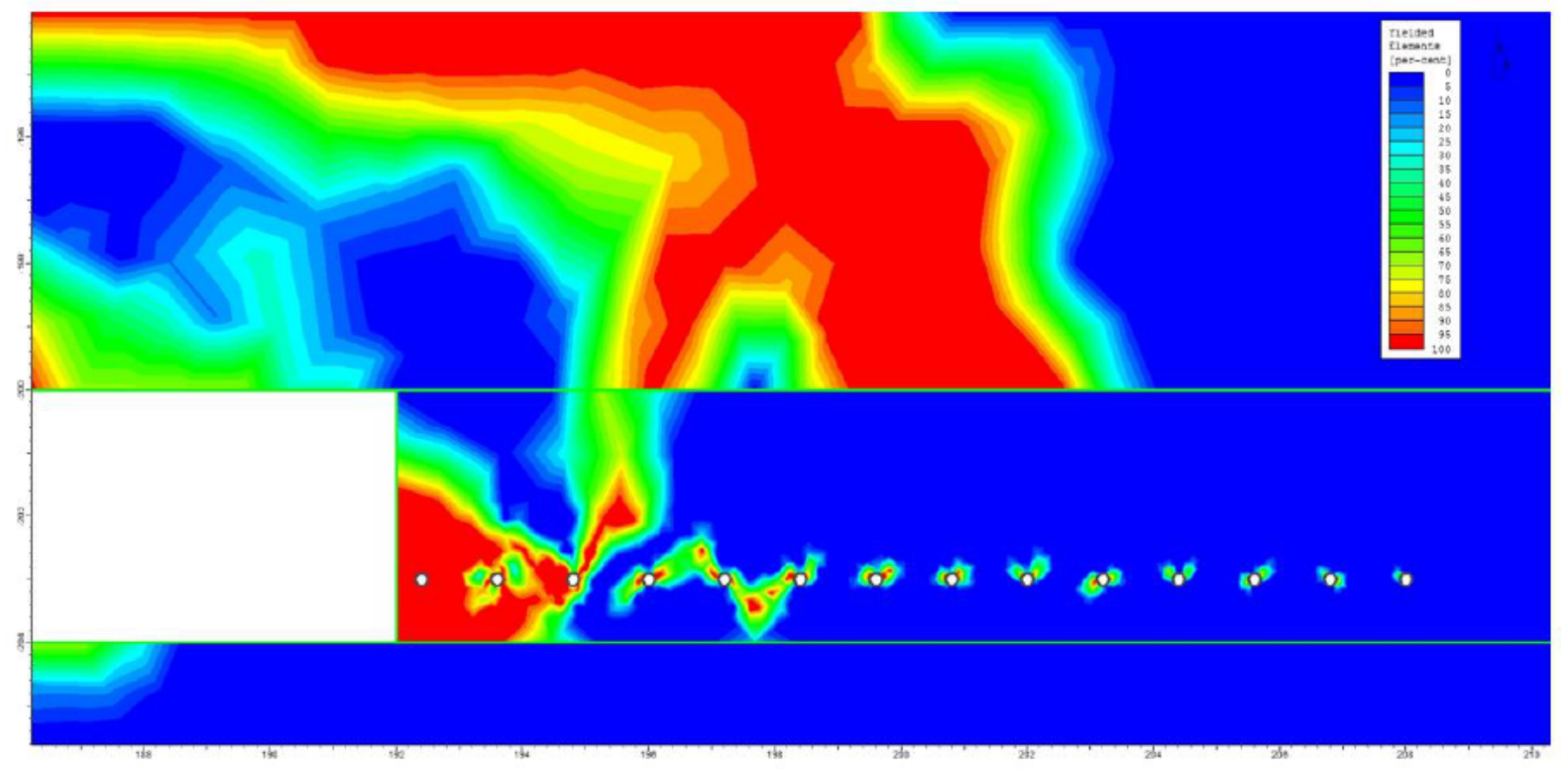

Figure 9 - Distribution of plastic ranges in stress in the massif with drilling relief boreholes with 1 m. spacing interval.

We note that drilling relief boreholes causes formation of stress concentration zones in the selvedge part of not attenuated massif. As a result, in stopping the coal face for disassembly of the longwall set of equipment, on the edge of the attenuated zone, the strength of the seam selvedge part and the rocks of the roofing located above the attenuated zone, reduces.

In this regard, to prevent the destruction of the rocks of immediate roofing on the recovery room edges, the destressing zone width should be adopted as bigger than the width of the prospective recovery room by the value of proliferation of increased stresses occurring in the seam selvedge part (in the extraction zone). The width of the extraction zone can be adopted as equal to half of the extracted height of the seam [12], that is, the destressing zone width should be established via equation (1)

$$
b_{\text {разг }}=b_{\text {дем.кам. }}+0.5 m_{6},
$$

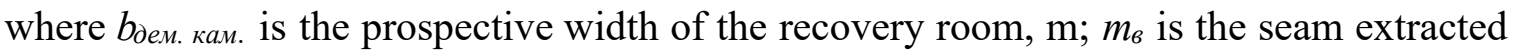
height, $\mathrm{m}$.

As a result of the performed analytical studies, the key parameters were identified of the recommended mode of stability enhancement of the immediate roofing rocks at the end sections of the recovery room via redistribution of the stresses occurring in the rock massif. These parameters include the relief boreholes' depth, their diameter and the width of the interborehole pillars, and also the width of the attenuated zone. Borehole drilling time (time period until longwall approaching, within which they should be drilled) is an insignificant parameter as the width of the inter-borehole pillars is selected in such a way that they operate as "rigid" beyond the bearing pressure zone, that is, they can bear loads for a provisionally long period 
of time (compared to the time of pillar mining), and the plastic properties (mechanical compliance) start manifesting only after pillars encounter the bearing pressure zone of the approaching longwall.

It should also be noted that the time of inter-borehole pillars being in the bearing pressure zone is directly proportional to the zone rate of advancing at the final stage of the extraction pillar mining. Considering the average rates of longwall advancing in mining gently-sloping coal seams of Kuznetsk Bazin (Russia), the duration of this period will be 7-9 days, out of them, for 4-5 days, inter-borehole pillars will be in the zone of increased stresses occurrence, causing their transformation into plastic (mechanically compliant) state.

\section{CONCLUSION}

In mining gently-sloping coal seams with longwalls along the stretch, the rocks of the immediate in the longwall areas adjacent to the site mine workings, limit state zones are formed, which causes rocks' loss of their bearing capacity. The main cause of the formation of these zones is the increased concentration of stresses in the longwall bearing pressure zone. This is one of the main causes of the increased intensity of the roof collapse in disassembly of longwall sets of equipment.

Preservation of the stable state of the rocks of immediate roofing can be obtained via destressing the immediate roofing at the end sections of the recovery room, adjacent to the panel preparatory workings.

As a mode of immediate roofing destressing in operations, it is recommended to conduct attenuation of the coal seam selvedge part within the abovementioned panels via drilling relief boreholes located parallel to the coal face.

The following key factors, significantly affecting the parameters of the recommended destressing are, should be considered: mining depth, seam extracted height and dip angle, the sequence of mining of extraction pillars within the flank (panel), degree of disturbance and the strength properties of the seam and the host rock massif.

The key parameters of the immediate roofing destressing are: destressing zone width, relief boreholes' depth, their diameter, spacing interval and the period until the longwall passage, as they must be drilled within this period.

For the conditions under consideration and similar conditions, the destressing zone width depends on the technologically required parameters of the recovery room and the extracted seam height, and it is determined by equation 1 .

The depth of the destressing zone from the side of panel entries, depending on mining depth, is determined via the graph constructed in the study (figure 6).

The relief borehole diameter, for reducing time consuming and manhours on organizational and technological activities, should be adopted as being equal to the diameter of degassing boreholes, and they should be drilled simultaneously. In the simulated conditions, this parameter was adopted as being equal to $0.2 \mathrm{~m}$.

Relief boreholes' spacing interval should be adopted of such a value so that the interborehole pillars could preserve their stability until longwall approaching, and the displacement of the rocks of immediate roofing at the time of the coal face system stopping, do not cause the immediate roofing loss of stability.

Drilling relief boreholes is recommended to be executed until they reach the longwall bearing pressure zone. 
The mode proposed for operations, enables to enhance the efficiency and safety of disassembly work in mining gently-sloping coal seams.

\section{REFERENCES}

[1] Basov, V.V. Evaluation procedure of conformance between numerical modeling and insitu measurement data on geomechanical parameters of rock mass near intersections in mines // Mining Informational and Analytical Bulletin, vol. 2019, no. 3, 2019, pp. 51-62.

[2] Galvin, J.M. Ground Engineering - Principles and Practices for Underground Coal Mining. - Springer International Publishing. - 2016. - 684 pp.

[3] Gridina, E.B. Comprehensive approach to managing the safety of miners in coal mines, / Gridina, E.B., Pasynkov, A.V., Andreev, R.E. / Innovation-Based Development of the Mineral Resources Sector: Challenges and Prospects - 11th conference of the RussianGerman Raw Materials, 2018, pp. 85.

[4] Han, C.L. Control technology and application for surrounding rock deformation in Tjunction area of gob-side entry retaining / Han, C.L., Zhang, N. \& Li, B.Y. // 2nd Global Conference on Civil, Structural and Environmental Engineering, GCCSEE 2013 Shenzhen, China, 28-29 September 2013.

[5] He, M. Longwall mining «cutting cantilever beam theory» and 110 mining method in China-The third mining science innovation // He, M., Zhu, G. \& Guo, Z. / Journal of Rock Mechanics and Geotechnical Engineering, vol. 7, no. 5, 2015, pp. 483-492.

[6] Karpov, G.N. Justification of longwall recovery technology in conditions of high performance mining: Ph.D. Dissertation in Engineering submitted to National mineral resources university «University of Mines». - Saint-Petersburg: National mineral resources university «University of Mines», 2013, $165 \mathrm{pp}$.

[7] Kang, H. Evaluation of the ground response of a pre-driven longwall recovery room supported by concrete cribs // Kang, H., H. Lv, X. Zhang and others / Rock Mechanics and Rock Engineering 49, no. 3: 2016, pp. 1025-1040.

[8] Kolikov, K.S. Stress-strain analysis in coal and rock mass under traditional mining with full caving and in technology with backfilling, / Kolikov, K.S., Manevich, A.I., Mazina, I.E. // Eurasian Mining, vol. 2018, no. 2, 2018, pp. 15-17.

[9] Liu, C. Accident analysis in relation to main roof structure when longwall face advances toward a roadway: A case study. / Liu, C., Z. Yang, P. Gong, K. Wang, X. Zhang, J. Zhang, and Y. Li. - Advances in Civil Engineering, vol. 2018, 2018.

[10] Liu, H. Numerical simulation and industrial test of boreholes destressing technology in deep coal tunnel / Liu, H., He, Y., Xu, J. \& Han, L. // Journal of the China Coal Society, vol. 32, no. 1, 2007, pp. 33-37.

[11] R. D. Magomet and A. S. Seregin, Enhancement of pre-mining methane drainage efficiency, Industry Safety and Labour Protection, No. 7, 2017, pp. 92-95.

[12] Makarov, A.B. Practical geomechanics. - Moscow: «Gornaya kniga» publishment, 2006. $-391 \mathrm{pp}$.

[13] Alexander Vladimirovich Nikiforov, Evgenii Alexandrovich Vinogradov, Alina Aleksandrovna Kochneva, Analysis of Multiple Seam Stability, International Journal of Civil Engineering and Technology (IJCIET) 10(2), 2019, pp. 1132-1139.

[14] Pariseau, W.G. Comparison of closure measurements with finite element model results in an underground coal mine in central Utah / Pariseau, W.G., McCarter, M.K. \& Wempen, J.M. // International Journal of Mining Science and Technology, vol. 29, no. 1, 2019, pp. 9-15.

[15] Peng, S.S. Coal Mine Ground Control: Third Edition. - NY: Wiley, 2008, 764 pp. 
[16] Rutty, Y. The evolution of pre-driven recovery roadways at crinum mine. // Rutty, Y., Payne, D., Mackenzie, A. / The 35th International Conference on Ground Control in Mining 2016, 80-87.

[17] Sengani, F. The application of the face-perpendicular preconditioning technique for destressing seismically active geological structures / Sengani, F. \& Amponsah-Dacosta, F. // Mining Technology: Transactions of the Institute of Mining and Metallurgy, vol. 127, no. 4, 2018, pp. 241-255.

[18] Smirniakov, V.V. Formation Peculiarities of Caving Zones as Aerodynamic Active Branches of Mine Ventilation Systems in Pillar Mining of Coal Beds / Smirniakov V.V., Smirniakova V.V. // Journal of Industrial Pollution Control, №33 (1), May 2017, pp. 864872.

[19] Smirniakov, V.V. Improving safety of mining operations by upgrading the methods of gas presence monitoring in the sheth grooves / Smirniakov V.V., Smirniakova V.V. // Journal of Industrial Pollution Control, No. 33 (1), May 2017, pp. 856-863.

[20] Smirnyakov V.V., Smirnyakova V.V. Unhandy factors in statistics of accidental gas and dust explosions in coal mines in Russia (2016) Gornyi Zhurnal Volume 2016, Issue 1, 1 January 2016, pp. 30-34.

[21] Song, G. A numerical modelling study of longwall face stability in mining thick coal seams in China / Song, G., Chugh, Y.P. \& Wang, J. // International Journal of Mining and Mineral Engineering -, vol. 8, no. 1, 2017, pp. 35-55.

[22] Zhang, P. Experience in ground control evaluation of longwall recovery using numerical modeling and in situ monitoring. Advances in Coal Mine Ground Control; 2017. p. 409437.

[23] Zhang, P. Roof failure in longwall headgates - Causes, risks, and prevention / Zhang, P., Van Dyke, M., Su, D., Esterhuizen, E. \& Trackemas, J. / 52nd U.S. Rock Mechanics/Geomechanics Symposium, Seattle, United States, 17-20 June 2018.

[24] Prakash Kumar and Rajak A.K, Advanced Functional Maintenance Management for Mining Excavator, International Journal of Mechanical Engineering and Technology (IJMET), Volume 5, Issue 4, April (2014), pp. 199-205.

[25] Thaker Minesh, S B Sharma and Yogesh Kosta, A Survey: Variants of Energy Constrained Reactive Routing Protocols of Mobile Ad Hoc Networks, International Journal of Electronics and Communication Engineering \& Technology, Volume 3, Issue 2, JulySeptember (2012), pp. 248-257.

[26] Deepalakshmi. R and Jothi Venkateswaran C, A Survey on Mining Methods for Protein Sequence Analysis: An Aerial View, International Journal of Computer Engineering and Technology (IJCET), Volume 3, Issue 2, July- September (2012), pp. 28-34. 